\title{
An Assessment of the Sustainable Tourism Development and Planning Approach of Kedarnath Pilgrimage Circuit Post 2013 Disaster
}

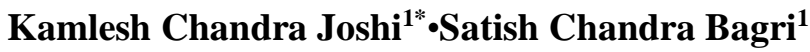 \\ ${ }^{1}$ Centre for Mountain Tourism and Hospitality Studies, HNB Garhwal University, Srinagar Garhwal \\ *Corresponding Author Email: kamaljoshi271@ gmail.com
}

Received: 4.8.2021; Revised: 24.8.2021; Accepted: 4.11.2021

(O) Society for Himalayan Action Research and Development

\begin{abstract}
Pilgrimage tourism practices are the oldest form of tourism in the Uttarakhand Himalayas. It is one of the most cultural and socio-economic activity in the mountain regions. The torrential rain and clouds bursts, in the year 2013, washed away the Kedarnath and Rambara to a large extent and made an unbearable loss in the Mandakini valley. Soon after the disaster, rebuilding of Kedarnath started. Although, a remarkable effort was made by various agencies to redevelop Kedarnath and surrounding areas but environmentalist and ecologists were of the view that the element of sustainable development was missing in the redevelopment process. It has been observed that due to unscientific and unsustainable development, the Himalayan regions are under threat and a dire need of sustainable development has been felt so that the needs of the guest and host can be fulfilled along with the protection of ecology and environment. The present paper is a case study on the reason of 2013 disaster and redevelopment of Kedar valley and its long-term sustainability post 2013 disaster. The research findings are based on the qualitative and quantitative research methods besides cross checking the documents available with the district administration of Rudraprayag.
\end{abstract}

Keywords: Pilgrimage, Himalayas, Sustainable development, Kedarnath redevelopment

\section{Introduction}

Kedarnath is the most remotely located Hindu pilgrim destination among the Char Dhams of Uttarakhand. It is situated on the bank of river Mandakini at the height of 3,583 meter above the mean sea level. The Kedarnath temple is one among the twelve jyotirlingas in the country and is the meeting ground of millions of domestic and foreign pilgrims. As per the data of Badri-Kedar Temple Committee and Uttarakhand Tourism Development Board (UTDB https://uttarakhandtourism.gov.in/), the tourist arrival in Kedarnath has exponentially increased from 87,629 in 1987 to $10,00,021$ in 2019 . However, the increasing number of footfalls and the limited carrying capacity of Kedarnath has opened a serious debate of sustainability especially after 2013 disaster.

In the last few years, a huge number of foot fall and growth of infrastructure has been observed in Kedar valley. Being in an ecosensitive zone, a minute anthropogenic or natural change can lead to a disaster in Kedarnath. The Rudraprayag district has faced natural disasters eight times in last 34 years in which millions of people suffered. More than 550 hydroelectric power projects are pipelined in Uttarakhand which may badly affect the drainage system of Alaknanda and Bhagirathi. It has also been observed that due to ongoing development of dams, roads and train tunnels, the incidents of landslides have been increased 
in the national highways of Garhwal Himalaya (Sharma et al., 2013).

After the 2013 disaster, geologists argued that the disaster was intensified by the unscientific infrastructure projects and human intervention around the flood plains (Chopra, 2013). Deforestation, increasing tourist foot fall and poor socio-economic conditions also contributed towards the vulnerability of the local people to disasters (NIDM, 2015). The redevelopment of Kedarnath, after disaster, arose many questions on the development process and its sustainability. It was considered that the redevelopment in the valley will be in the line of sustainable development approach and benefits to all the stakeholders as the very purpose of 'sustainable development' is a holistic development process that manage the resources in such a way that the economic, social and cultural needs of the host community can be fulfilled, while developing and maintaining the sustainability of a tourist destination

(UNWTO

\section{https://www.unwto.org/sustainable-}

\section{development)}

\section{Review of Literature}

Kedarnath is one of the toughest pilgrim treks in the Himalayan region. The flash flood of 2013 brings it into limelight and the world came to know about this high-altitude pilgrim destination. Right after the disaster, the debate of sustainable development in Himalaya took place in academic world. United Nations (1987; https://www.un.org/en/ga/president/65/iss ues/sustdev.shtml)defined sustainable development as "meeting the needs of the present without compromising the ability of future generations to meet their own needs". Swarbrooke (1999) was of the view that the negative impacts of mass tourism gave birth to the concept of "green tourism" which further pave path for the emergence of sustainable tourism development.

Kaul and Gupta (2009) said that the balance between sustainable development and pilgrimage tourism not only improve the economic conditions but must also play a significant role in the promotion of environmental, socio-cultural harmony. Telfer and Sharpley (2015) opined that the ecosensitive development can lead to the sustainable tourism which is opposite to that of mass tourism. Ahmed (2013) defined three dimensions of sustainable tourism development (i) optimal use of environmental resources, (ii) socio-cultural authenticity of host communities, and (iii) long-term economic operations. United Nations Sustainable Development (1992) further stated that to make mountain ecosystem more sustainable, local people should be given incentives for the use and transfer of environment-friendly technologies and farming and conservation practices.

The disaster of 2013 and redevelopment of Kedarnath raised some important and logical questions on the sustainability of the Kedarnath as a destination. The NIDM (2015) report considered it as one of the deadliest disasters in the human history with huge loss of lives and wide spread destruction. The Mandakini valley 
faced a torrential rain that is coupled with the collapse of the Chorabari Lake and led to the destruction from Kedarnath shrine to Guptakashi and Rudraprayag in the valley. Thousands of visitors stranded at various parts of the state due to lack of communication, blockage of roads, landslides, and flash flood. Dobhal et. al. (2013) found that the meteorological stations near Chorabari glacier recorded $325 \mathrm{~mm}$ rainfall at the base of the glaciers on 15 and 16 June 2013. The cloud bursts and heavy rain (natural cause) led to the flash flood and it was further intensified by the man-made causes like deforestation, hydroelectric power projects, illegal construction on river beds, and poorly planned tourism activities.

The disaster of 2013 not only caused irreparable loss to the state but also damaged precious lives, infrastructure, private and public properties and many others. Pilgrims and locals were killed by flash floods and thousands were missed. Many people died due to scarcity of food, water and medicine (Sharma et al., 2014). The infrastructure was badly affected in Kedarnath Pilgrim routes. The estimated loss of infrastructure was valued at tens of billion rupees by the officials (Mazoomdar and Langer, 2013). According to the survey of PHD Chamber of Commerce and Industry (PHDCCI), the state lost more than Rs. 120 billion from tourism sector alone in 2013-14. It was also expected that this loss would rise to about Rs. 200 billion in 2014-15 (The Hindu Business Line, 2013).
The JSW (formerly known as Jindal South West) group proposed a plan and design for reconstruction of Kedarnath temple area that was washed away and damaged significantly in flash floods of 2013. Soon after the disaster redevelopment work was started under the supervision of NIM (Nehru Institute of Mountaineering). After the marathon efforts of all the stakeholders, a $20 \mathrm{~km}$ long route from Sonprayag to Kedarnath took a fresh look. New resting camps were established at Choti and BadiLincholi with modern amenities and facilities (Joshi, 2016).

\section{Research Methodology}

The research methodology was carried out at regional level. The researcher visited the study area in 2020 and collected the relevant qualitative and quantitative data through the primary and secondary sources. For the primary data collection, a 5-point Likert-scale (2010) questionnaire was used. The sample size included 227 local respondents. Finally, the information obtained from the respondents was analysed with the help of SPSS26.0 and reliability test, descriptive analysis, one sample t-test and Factor analysis were applied to process the data for the final results and findings.

Several research papers, Government official reports, Ministry of tourism and State tourism board's report etc. were also referred to get a deep insight in the research topic. Adhered to the objectives of the research paper, personal interviews with the eminent environmentalist like Chandi Prasad Bhatt and Sekhar Pathak 
were organised as a source of primary data. However, secondary sources comprise of magazines, journals, daily newspapers, books and articles were also used to compile updated information.

\section{Objectives of the study}

(i) To study the major reasons of 2013 disaster

(ii) To study and analyse the sustainability of ongoing redevelopment work

\section{Data Analysis}

Quantitative data was gathered from the local community, who were the key stakeholders in the study area. Major questions in questionnaire were asked to inquire the reason of 2013 disaster and the redevelopment and sustainability of the ongoing work in Kedarnath. The demographic profile of the respondents has been mentioned in Table 1 .

Table 1: Demographic profile

\begin{tabular}{llll}
\hline $\begin{array}{l}\text { DEMOGRAPHIC } \\
\text { PROFILE }\end{array}$ & VARIABLES & FREQUENCY & PERCENT (\%) \\
\hline Gender & Male & 153 & 67.4 \\
& Female & 74 & 32.6 \\
Age Groups & Below 25 & 13 & 5.7 \\
& $25-40$ & 170 & 74.9 \\
Marital Status & $40-60$ & 44 & 19.4 \\
& Married & 186 & 81.9 \\
Education & Unmarried & 41 & 18.1 \\
& Below 10th & 4 & 1.8 \\
& 12th & 134 & 59.0 \\
Occupation & Under Graduate & 88 & 38.8 \\
& Post Graduate & 1 & 0.4 \\
& Govt. & 1 & 0.4 \\
& Private & 45 & 19.8 \\
& Businessman & 111 & 48.9 \\
& Farmer & 33 & 14.5 \\
& Student & 22 & 9.7 \\
& Other & 15 & 6.6 \\
\hline
\end{tabular}

Source: Field study

\section{Descriptive Statistics}

In the descriptive statistics the mean and standard deviation of each variable was calculated to get the final interpretation.

Table 2: Reasons of Disaster (N: 227)

\begin{tabular}{|c|c|c|c|c|c|}
\hline VARIABLES & CODE & MEAN & $\begin{array}{l}\text { STANDARD } \\
\text { DEVIATION }\end{array}$ & $\begin{array}{l}\text { PERCENTAGE } \\
(\%)\end{array}$ & INTERPRETATION \\
\hline Extreme Rainfall & RoD1 & 4.62 & 0.608 & 92.33 & Strongly Agree \\
\hline Cloudbursts & RoD2 & 4.56 & 0.638 & 91.19 & Strongly Agree \\
\hline $\begin{array}{l}\text { Formation \& collapse of } \\
\text { Chorabari lake }\end{array}$ & RoD3 & 4.57 & 0.671 & 91.37 & Strongly Agree \\
\hline Melting of glaciers & RoD4 & 3.22 & 0.832 & 64.32 & Agree \\
\hline Massive landslide & RoD5 & 3.48 & 0.59 & 69.6 & Agree \\
\hline Increasing global warming & RoD6 & 3.46 & 0.618 & 69.25 & Agree \\
\hline Deforestation & RoD7 & 4.16 & 0.599 & 83.26 & Strongly Agree \\
\hline Unplanned and illegal & RoD8 & 4.27 & 0.853 & 85.37 & Strongly Agree \\
\hline
\end{tabular}


construction

Excessive footfall of tourists

$\begin{array}{lllll}\text { RoD9 } & 3.2 & 0.936 & 63.96 & \text { Agree } \\ \text { RoD10 } & 4.73 & 0.464 & 94.63 & \text { Strongly Agree }\end{array}$

Ignorance of sustainable

development approach

Table 2 reflects the opinion of local community regarding the statements of reasons of 2013 disaster in

Kedarnath.

Table 3: Redevelopment and it's Sustainability (N: 227)

\begin{tabular}{|c|c|c|c|c|c|}
\hline Variables & Code & Mean & $\begin{array}{l}\text { Standard } \\
\text { Deviation }\end{array}$ & $\begin{array}{l}\text { Percentage } \\
(\%)\end{array}$ & Interpretation \\
\hline $\begin{array}{l}\text { Sustainability as first and foremost } \\
\text { requirement }\end{array}$ & RDS1 & 4.86 & 0.344 & 97.27 & Strongly Agree \\
\hline $\begin{array}{l}\text { Redevelopment follows sustainability } \\
\text { approach }\end{array}$ & RDS2 & 3.91 & 0.767 & 78.15 & Agree \\
\hline $\begin{array}{l}\text { Community confidence while } \\
\text { implementing any project }\end{array}$ & RDS3 & 2.42 & 0.732 & 48.37 & Disagree \\
\hline Redevelopment affecting local climate & RDS4 & 3.74 & 0.744 & 74.89 & Agree \\
\hline $\begin{array}{l}\text { Use of concrete \& cement increase local } \\
\text { warming }\end{array}$ & RDS5 & 4.59 & 0.544 & 91.81 & Strongly Agree \\
\hline Heli services affecting local bio-diversity & RDS6 & 2.86 & 0.780 & 57.18 & Disagree \\
\hline Construction on moraines is dangerous & RDS7 & 4.01 & 0.839 & 80.26 & Strongly Agree \\
\hline $\begin{array}{l}\text { Redevelopment save the temple from } \\
\text { future disasters }\end{array}$ & RDS8 & 3.70 & 0.723 & 73.92 & Agree \\
\hline $\begin{array}{l}\text { Increasing number of tourists increases } \\
\text { more pollution }\end{array}$ & RDS9 & 4.21 & 0.621 & 84.14 & Strongly Agree \\
\hline $\begin{array}{l}\text { Tourism amenities \& hotels destroying } \\
\text { local ecosystem }\end{array}$ & RDS10 & 3.95 & 0.760 & 79.03 & Agree \\
\hline
\end{tabular}

Table 3 reflects the opinion of local community regarding the variables of redevelopment and its sustainability in Kedar valley.

One Sample t-test

REASONS OF 2013 DISASTER

Test Value 3

\begin{tabular}{lcccccc}
\hline Code & t- Value & df & Sig. (2-tailed) & Mean Difference & $\begin{array}{c}\text { 95\% Confidence Interval of the } \\
\text { Difference }\end{array}$ \\
& & & & & Lower & Upper \\
\hline RoD1 & 40.037 & 226 & 0.000 & 1.61674 & 1.5372 & 1.6963 \\
RoD2 & 36.836 & 226 & 0.000 & 1.55947 & 1.4760 & 1.6429 \\
RoD3 & 35.225 & 226 & 0.000 & 1.56828 & 1.4806 & 1.6560 \\
RoD4 & 3.909 & 226 & 0.000 & 0.21586 & 0.1071 & 0.3247 \\
RoD5 & 12.263 & 226 & 0.000 & 0.48018 & 0.4030 & 0.5573 \\
RoD6 & 11.269 & 226 & 0.000 & 0.46256 & 0.3817 & 0.5434 \\
RoD7 & 29.274 & 226 & 0.000 & 1.16300 & 1.0847 & 1.2413 \\
RoD8 & 22.398 & 226 & 0.000 & 1.26872 & 1.1571 & 1.3803 \\
RoD9 & 3.190 & 226 & 0.002 & 0.19824 & 0.0758 & 0.3207 \\
RoD10 & 56.245 & 226 & 0.000 & 1.73128 & 1.6706 & 1.7919 \\
\hline & & & Redevelopment and sustainability & & 1.9084 \\
RDS1 & 81.580 & 226 & 0.000 & 1.86344 & 1.8184 & 1.0078 \\
RDS2 & 17.819 & 226 & 0.000 & 0.90749 & 0.8071 & -0.4857 \\
RDS3 & -11.962 & 226 & 0.000 & -0.58150 & -0.6773 & 0.8418 \\
RDS4 & 15.072 & 226 & 0.000 & 0.74449 & 0.6472 & 1.6615 \\
RDS5 & 44.039 & 226 & 0.000 & 1.59031 & 1.5192 & -0.0390 \\
RDS6 & -2.723 & 226 & 0.007 & -0.14097 & -0.2430 & 1.1229
\end{tabular}




\begin{tabular}{ccccccc} 
RDS8 & 14.511 & 226 & 0.000 & 0.69604 & 0.6015 & 0.7906 \\
RDS9 & 29.266 & 226 & 0.000 & 1.20705 & 1.1258 & 1.2883 \\
RDS10 & 18.869 & 226 & 0.000 & 0.95154 & 0.8522 & 1.0509 \\
\hline
\end{tabular}

Note: Data interpretation criteria [t $>1.96(+$ or -$)], \mathrm{p}<0.050$, Value Zero is not present between Lower Limit and Upper Limit)

\section{Factor Analysis}

To describe the available variability between the observed and correlated variables, Factor analysis was used as a statistical tool. It also measures the relation between various subfactors and variables and find the components which different factors and sub-factors will load on them and measure their reliability. To narrow down a set of variables, Principal Component Analysis method of factor analysis was used. The variables having the maximum variance in the data set were observed to form a component.

\section{Analysing various dimensions of Reasons of 2013 disaster}

With the help of Kaiser-Meyer-Olkin test the adequacy of sample was analysed. KMO find out the usefulness of data for factor analysis and relationship between the variables.

\section{Table 6: KMO and Bartlett's test}

\begin{tabular}{lcc}
\hline Kaiser-Meyer-Olkin Measure of Sampling Adequacy. & \multicolumn{2}{c}{$\mathbf{0 . 7 6 7}$} \\
\hline Bartlett's Test of Sphericity & Approx. Chi-Square & 523.219 \\
& $\mathrm{df}$ & 45 \\
& Sig. & 0.000 \\
\hline
\end{tabular}

For the above dimension KMO and Bartlett's test had a KMO value of 0.767 which is greater than 0.50 and significant at $5 \%$ level $(\mathrm{p}=.000<.05)$.

Table 7: Average Variance and Consolidated Factors

\begin{tabular}{llcccc}
\hline Factors & Codes & \multicolumn{2}{c}{ Components } & \multirow{2}{*}{ AVE* $^{*}$} & \multirow{2}{*}{ CR** $^{* *}$} \\
\cline { 2 - 3 } Natural Reason & & $\mathbf{1}$ & $\mathbf{2}$ & & \\
& RoD1 & $\mathbf{0 . 8 0 9}$ & & 0.602 & 0.883 \\
& RoD3 & $\mathbf{0 . 7 8 5}$ & & & \\
& RoD2 & $\mathbf{0 . 7 7 6}$ & & & \\
& RoD5 & $\mathbf{0 . 7 7 5}$ & & & \\
& RoD4 & $\mathbf{0 . 7 3 3}$ & & & \\
Man-made Reason & RoD8 & & $\mathbf{0 . 8 7 8}$ & 0.635 & \\
& RoD9 & & $\mathbf{0 . 8 2 3}$ & & \\
& RoD6 & & $\mathbf{0 . 7 9 8}$ & & \\
& RoD7 & & $\mathbf{0 . 7 6 7}$ & & \\
& RoD10 & & $\mathbf{0 . 7 1 0}$ & &
\end{tabular}

Extraction Method: Principal Component Analysis

Rotation Method: Varimax with Kaiser Normalization

*AVE: Average Variance Extracted **CR: Composite Reliability 


\section{Analysing various dimensions of Redevelopment and Sustainability}

Table 8: KMO and Bartlett's test

\begin{tabular}{lcc}
\hline $\begin{array}{l}\text { Kaiser-Meyer-Olkin Measure of Sampling } \\
\text { Adequacy. }\end{array}$ & $\mathbf{0 . 7 8 9}$ \\
\hline Bartlett's Test of Sphericity & Approx. Chi-Square & 301.769 \\
& df & 45 \\
& Sig. & 0.000 \\
\hline
\end{tabular}

In the above dimension, KMO and Bartlett's test had a KMO value of 0.789 which is greater than 0.50 and significant at $5 \%$ level $(\mathrm{p}=.000<.05)$. The value of KMO test also shows significant adequacy.

Table 9: Average Variance and Consolidated Factors

\begin{tabular}{llcccc}
\hline \multirow{2}{*}{ Factors } & Codes & \multicolumn{2}{c}{ Components } & \multirow{2}{*}{ AVE } & CR \\
\cline { 3 - 4 } & & $\mathbf{1}$ & $\mathbf{2}$ & & \\
\hline Need of Sustainability & RDS7 & $\mathbf{0 . 7 3 2}$ & & 0.813 \\
& RDS2 & $\mathbf{0 . 7 2 0}$ & & & \\
& RDS10 & $\mathbf{0 . 7 2 7}$ & & & \\
& RDS8 & $\mathbf{0 . 7 0 9}$ & & & \\
\hline Redevelopment & RDS3 & & $\mathbf{0 . 8 5 4}$ & & \\
Implications & RDS6 & & $\mathbf{0 . 8 4 0}$ & & \\
& RDS5 & & $\mathbf{0 . 7 9 3}$ & 0.620 & \\
& RDS9 & & $\mathbf{0 . 7 7 4}$ & & \\
& RDS4 & & $\mathbf{0 . 7 4 2}$ & & \\
& RDS1 & & $\mathbf{0 . 7 1 2}$ & &
\end{tabular}

\section{Extraction Method: Principal Component Analysis}

Rotation Method: Varimax with Kaiser Normalization

In both the Tables 7 and 9, It is revealed that the total variance of the highlighted values were more than 60 percent and their eigen value was also greater than 1 . It means these components can explain the maximum variance existing in the factors. Similarly, factor loadings appeared greater than 0.6, $\mathrm{AVE}>0.5$ and $\mathrm{CR}>\mathrm{AVE}$ criterions. The

\section{Results and Discussions}

The above data analysis has fulfilled both the objectives of the research paper. The first objective was to study the reasons of disaster in Kedarnath and on the basis of the available findings it is reflected that the Kedarnath disaster of 2013 was the result of both natural responses in Table 7revealed that the locals were agreed with the statements of various reasons of disaster in the valley. Whereas, the responses of Table 9 clearly indicates that there is a great need of sustainable development approach to be followed in the redevelopment works.

and man-made causes. The descriptive analysis, one-sample t-test and factor analysis indicated that the respondents were totally agreed with both the reasons of the disaster. The second objective was to study and analyse the sustainability of ongoing development work. From the descriptive analysis and t-test, 
and factor analysis, it was noticed that the respondents were disagreed with the variable that the local people were taken into confidence before implementing any development project in the valley. They were also disagreed with the impact of heli serviceson the local biodiversity. Except these Some of the major proposed and ongoingconstruction and redevelopment works in Kedarnath are as following:

1. Street widening and grading of the path towards Kedarnath temple (Fig 1)

2. Ghats for prayer on the bank of Saraswati River (Fig 2)

3. A three-tier protection wall behind the temple (Fig 3)

4. Shankaracharya Samadhi and virtual museum (Fig 4)

5. Construction of the houses of the Tirth Purohits

6. Renovation of Mandakini Ghats and retaining wall

7. Guests houses for tourists

8. Smriti van memorial

9. Meditation caves

10. Flood protection wall and Ghats two variables, the respondents were agreed with other variables of the construct. The factor analysis also indicates the need of sustainable development approach in the valley otherwise the implications of myopic redevelopment will have a negative impact on destination and surrounding area.

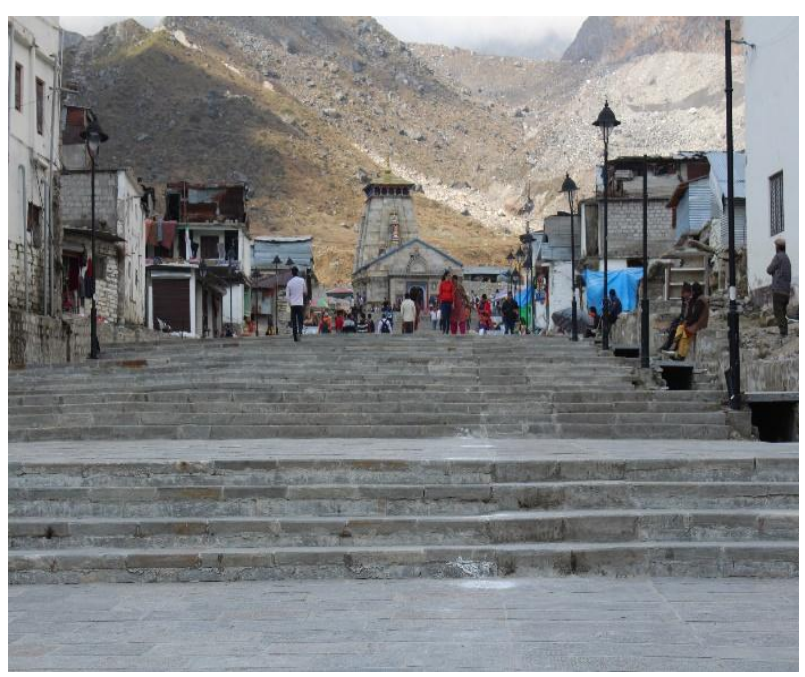

Fig.1: Street widening \& grading

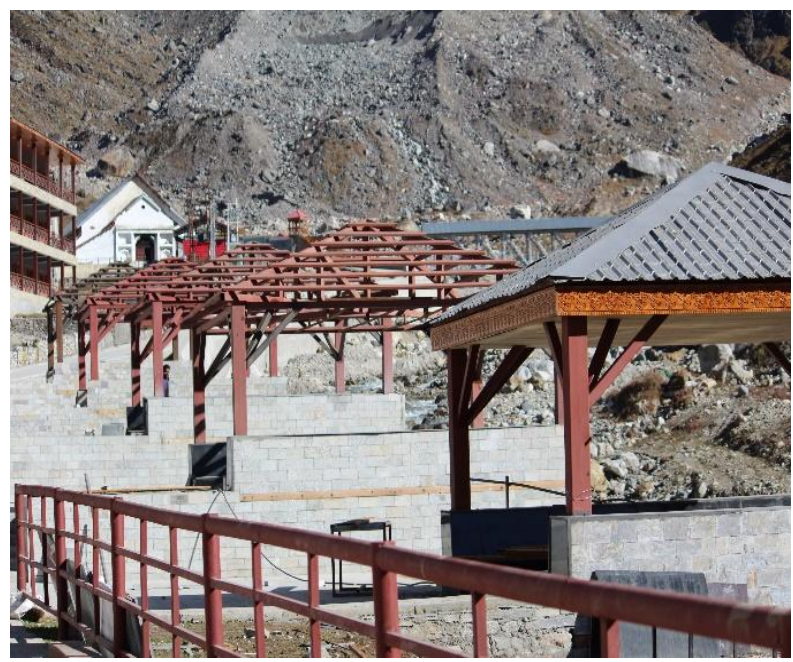

Fig. 2: Ghats for Prayer 


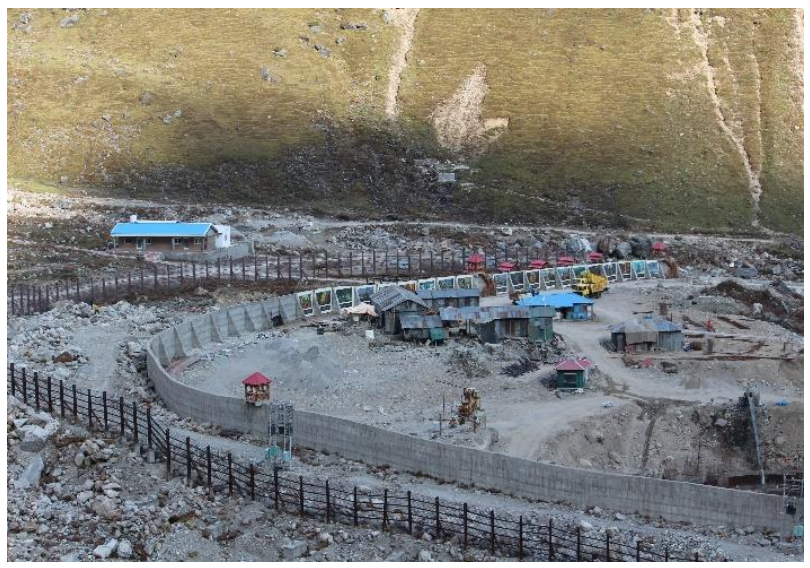

Fig. 3: A three-tier protection

wall

While the redevelopment was taking place in Kedarnath, environmentalist raised some serious scientific and environmental concern regarding it. The fresh moraine deposited in Kedarnath in not suitable for the heavy RCC construction in the region. The construction work in the loose sedimentary deposit may have serious implications in future (Joshi, 2016). The earth scientists believe that the deforestation, illegal construction along the riverbed and increasing anthropogenic activities had an adverse effect on the ecological balance of Himalayan region (Sati, 2014). Melting of glaciers, flash floods, torrential rain, cloudbursts etc are the consequences of global warming, climate change and human interference in nature (Valdiya, 2010). There is no doubt that the team of NIM with other agencies had worked bravely in the high altitude of Kedarnath but the lack of foresight in planning and use of concrete and heavy construction material can led to the further disaster in future (Joshi, 2017).

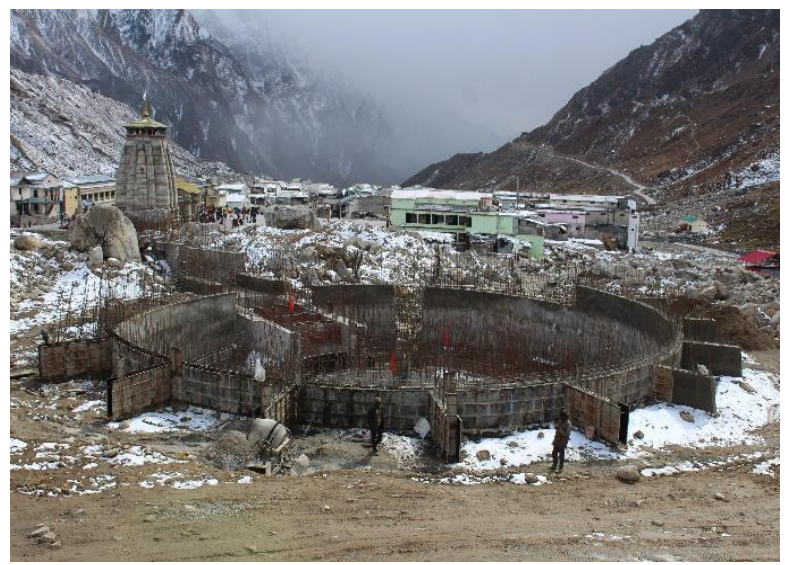

Fig. 4: Adi Shankaracharya Samadhi(Photo

\section{Courtesy: Kamlesh Chandra Joshi)}

While interviewing environmentalist Chandi Prasad Bhatt, it was conveyed that blind folded development may destroy the Himalaya. There is a need of enhancive development in this fragile and sensitive zone. All developmental works should be done in a sustainable manner to keep the future generations in mind. He further elaborated that the present redevelopment work in Kedarnath is unscientific that can have serious consequences in due course of time. All the redevelopment work has been done on the unconsolidated moraines which can lead to future disasters.

While interviewing historian Sekhar Pathak, he was of the view that the increasing number of the tourists have diluted the concept of pilgrimage. In the earlier days it was a life time experience to visit Kedarnath shrine but now tourists are visiting Kedarnath for thrill and enjoyment. Modern tourism has encroached pilgrimage tourism and converted the destination into a picnic spot. The increasing number of tourists in Kedarnath need to be regulated otherwise the problem of pollution, local warming, destruction of biodiversity and 
illegal construction will lead some drastic consequences in future.

There is a dire need of sustainable development model with clear vision, roadmap and set of policies for the Himalayan regions. An allround development i.e., social, economic and environmental should go hand in hand and resources must be exploited in such a way that they remain for the future generations as well. An Environment Impact Assessment (EIA) and Social Impact Assessment (SIA) must be undertaken before implementing any development projects in the high altitudes. Use of cement and concrete in construction should be avoided, instead local traditional woods can be used for the accommodation units. The local community should be taken into confidence before implementing any development projects. Sustainable development is the first and foremost requirement of the Himalaya, it should be kept in mind while doing development in the high altitudes.

\section{Limitation and Recommendation for future research}

- The data for the above study was gathered from the local respondents only.

- The data was collected from Kedarnath only.

- The present study is based on cross sectional data. Future researcher can do a longitudinal study between locals and tourists as well.
- Extracted factors in the study are recommended to test in another location also.

\section{References}

Ahmed N (2013). Sustainable Tourism Development in Uttarakhand Region of India, International Journal of Management and Social Sciences Research, Volume 2, No. 4.

Chopra R (2013). "The untold story from Uttarakhand", The Hindu, 25 June, 2013. URL:

https://www.thehindu.com/opinion/lead/th e-untold-story-from-

uttarakhand/article4847166.ece

Dobhal DP, Gupta A, Mehta M, and Khandelwal DD (2013). Kedarnath disaster: Facts and plausible causes, current science, Vol. 105, No. 2, pp 171174

Joshi H (2016). Kedarnath: 3 Years After The Disaster. URL: https://www.ndtv.com/blog/kedarnath -3-years-after-the-disaster-1420538

Joshi R (2017). In Rebuilding Kedarnath, a New Disaster in the Making. The Wire. URL: https://thewire.in/environment/kedarn ath-temple-rebuilding-flood-lessons

Kaul H and Gupta S (2009). Sustainable Tourism in India. Worldwide Hospitality and Tourism Themes, 1(1), pp. 12-18.

Mazoomdar J and Langer A (2013). 'Uttarakhand: A model of disaster', Tehelka v.10 no.27, New Delhi.

NIDM (2015). Uttarakhand Disaster 2013. National Institute of Disaster Management 
(Ministry of Home Affairs, Government of India). URL: https://nidm.gov.in/PDF/pubs/ukd-p1.pdf

Sati SP (2014). Developmental Planning and Geological Constraints in Uttarakhand Himalaya. Uttarakhand Disaster: Contemporary Issues of Climate Change and Development with Holistic Approach. Winsar Publishing Co., Dehradun, Uttarakhand.

Sharma AK, Prakash S, and Roy TKS (2014). Response to Uttarakhand Disaster 2013. International Journal of Scientific \& Engineering Research, Vol. 5, Issue 10.

Sharma M, Mishra SK, and Tyagi S (2013). The Impact of Torrential Rainfall in Kedarnath, Uttarakhand, India during June, 2013, International Research Journal of Environment Sciences, Vol. 2(9), 34-37.

Swarbrooke J (1999). Sustainable Tourism Management. New York: CABI.

Telfer DJ and Sharpley R (2015). Tourism and development in the developing world. London: Routledge.

The Hindu Business Line (2013). Floods may cause Rs $12 \mathrm{~K}$ cr loss for Uttarakhand tourism sector: Survey. URL: https://www.thehindubusinessline.co

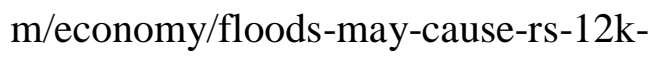
cr-loss-for-uttarakhand-tourismsector-survey/article23101747.ece\#

United Nations Sustainable

Development (1992). The UN Conference on Environment \& Development, Rio de Janerio, Barzil, 3 to 14 June 1992, URL: https://sustainabledevelopment.un.
org/content/documents/Agenda21.p df

Valdiya KS (2010). The Making of India: Geodynamic Evolution. New Delhi: MacMillian.

5-Point Likert Scale (2010) In: Preedy VR, Watson RR (eds) Handbook of Disease Burdens and Quality of Life Measures. Springer, New York,

NY.https://doi.org/10.1007/9780-387-78665-0_6363 